\title{
Drying of virus-containing particles: modelling effects of droplet origin and composition
}

\author{
Michael C. Jarvis ${ }^{1}$ i]
}

Received: 14 April 2021 / Accepted: 17 October 2021 / Published online: 5 November 2021

(c) The Author(s) 2021

\begin{abstract}
Background and purpose Virus-containing aerosol droplets emitted by breathing, speech or coughing dry rapidly to equilibrium with ambient relative humidity $(\mathrm{RH})$, increasing in solute concentration with effects on virus survival and decreasing in diameter with effects on sedimentation and respiratory uptake. The aim of this paper is to model the effect of ionic and macromolecular solutes on droplet drying and solute concentration.

Methods Deliquescence-efflorescence concepts and Kohler theory were used to simulate the evolution of solute concentrations and water activity in respiratory droplets, starting from efflorescence data on mixed $\mathrm{NaCl} / \mathrm{KCl}$ aerosols and osmotic pressure data on respiratory macromolecules.

Results In $\mathrm{NaCl} / \mathrm{KCl}$ solutions total salt concentrations were shown to reach $10-13 \mathrm{M}$ at the efflorescence $\mathrm{RH}$ of $40-55 \%$, depending on the K:Na ratio. Dependence on K:Na ratio implies that the evaporation curves differ between aerosols derived from saliva and from airway surfaces. The direct effect of liquid droplet size through the Kelvin term was shown to be smaller and restricted to the evolution of breath emissions. Modelling the effect of proteins and glycoproteins showed that salts determine drying equilibria down to the efflorescence $\mathrm{RH}$, and macromolecules at lower RH.

Conclusion Differences in solute composition between airway surfaces and saliva are predicted to lead to different drying behaviour of droplets emitted by breathing, speech and coughing. These differences may influence the inactivation of viruses.
\end{abstract}

Keywords Evaporation $\cdot$ SARS-CoV-2 $\cdot \mathrm{HRV}-16 \cdot$ Water activity $\cdot$ Virus inactivation $\cdot$ Efflorescence

\section{Introduction}

Some respiratory viruses can be transmitted in aerosol form, as well as in larger droplets and surface deposits [1]. Aerosols are conventionally defined as droplets or particles less than 5-10 $\mu \mathrm{m}$ in diameter that, according to Stokes' Law, remain suspended in still air for minutes or longer [2]. It has been argued $[3,4]$ that the size range should be extended to 50-100 $\mu \mathrm{m}$ because turbulence, either in a cough jet [5] or due to draughts [6] or convection [7], keeps larger particles airborne for longer than is predicted by Stokes' Law.

Despite initial doubts, it is now quite widely accepted that certain viruses including SARS-CoV-2 are transmitted in aerosols, particularly from asymptomatic subjects [8, 9]. Aerosol transmission is most likely in enclosed spaces

Michael C. Jarvis

michael.jarvis@glasgow.ac.uk

1 School of Chemistry, Glasgow University, Glasgow, Scotland G12 8QQ, UK such as schools, public buildings and transportation [10]. Aerosols can transmit viruses from person to person with transiently inadequate social distancing [4], but they can also build up, over minutes to hours, throughout the air in an enclosed space so that the risk of infection depends on the duration of emission and exposure, not on distance [11]. In these circumstances the risk depends on Wells-Riley dynamics and is reduced by ventilation with fresh or filtered air and by anything that decreases the viable lifetime of the virus [11].

The viable lifetime of an airborne virus depends on the virus and its environment [12]. SARS-CoV-2 remains viable indoors for minutes to hours [13-16]. The rate of inactivation is enhanced by sunlight [17] and by increasing temperature [17, 18], and is influenced by humidity [17] and by the medium in which the virus is suspended [13]. Because temperature influences relative humidity it is not clear whether the effects of temperature and humidity are wholly independent [19], and the nature and mechanism of the humidity effect are still poorly understood. 
For some viruses inactivation is faster at intermediate levels of relative humidity, around $40-60 \%$, than at high or very low humidity [20]. This pattern was observed in two recent studies, on the non-enveloped common cold virus HRV-16 [21] and on influenza virus A, an enveloped virus [22]. In both studies the virus was inactivated faster at $60 \% \mathrm{RH}$ when it had been dried from higher RH than when it had been hydrated from lower RH [21, 22]. This observation was explained as follows, based on an "Efflorescence-deliquescence differential inactivation" model.

As an aerosol droplet in dry air loses water by evaporation, its salt concentration rises and its water activity falls. At the efflorescence RH the salt precipitates, the activity of the residual water is transiently restored and the droplet dries abruptly [23]. If precipitation is retarded by lack of nuclei for crystallisation, the solution enters a metastable state and the efflorescence RH is then lower than the deliquescence RH at which dissolution occurs when a dry droplet is hydrated [24]. In the hysteresis region between the efflorescence and deliquescence limits (typically about $35 \%$ to $65 \% \mathrm{RH}$ ) [25], the salt concentration can rise considerably above that predicted from equilibrium solubility. It was suggested [21, 22] that high salt concentration inactivated the HRV-16 and IVA viruses.

It is unclear whether SARS-CoV-2 behaves similarly to HRV-16 and IVA. The limited evidence available at present $[13,17,19,26]$ suggests that SARS-CoV-2 may be least stable at high humidity, but differences in methods and the nature of the ambient solution make it difficult to draw detailed conclusions. The inactivation of SARS and SARS$\mathrm{CoV}-2$ in surface deposits is slower than inactivation in aerosols but its rate generally increases with increasing humidity [27-29]. Whatever the mechanism, the inactivation of viruses [20, 30] and SARS-CoV-2 in particular [29] is widely considered to depend on available water. Water availability, expressed as the water activity $\mathrm{a}_{\mathrm{w}}$, increases with the ambient RH but is also modulated by changing surface tension through the Kelvin effect in small aerosol droplets [31].

Due to their influence on virus stability, the salt concentrations and water activity in aerosol-sized droplets deserve closer examination. The same is true for surface deposits, particularly because it is not known why viral viability is enhanced in that form $[15,32]$. The drying of aerosols when emitted into ambient air has been quite extensively studied [33-35] and modelled [33, 34, 36], often with the aim of predicting when droplets, initially large enough to sediment in still air, will shrink enough to remain suspended. For the largest droplets this depends on the kinetics of drying: they fall to the floor before they have time to dry $[33,34]$, although the falling and drying times both depend on turbulence [4]. For smaller droplets drying is rapid and it is the equilibrium (strictly, quasi-equilibrium) with the ambient RH that matters [37]. Drying equilibria depend on relative humidity whereas drying rate, and hence the rate at which large droplets settle out, depends on absolute humidity [37].

In the biomedical literature, a droplet that has dried to equilibrium is called a droplet nucleus [1]. Depending on the solids present and the moisture that their hygroscopicity retains, a droplet nucleus may consist of a very concentrated solution, a polycrystalline salt precipitate, a protein gel or amorphous solid, or a combination of these phases; presenting very different environments in which viruses may be inactivated [38]. For example, thermal denaturation depends on mobile water [20, 30, 39]. Also polycrystalline or other solids may refract or absorb daylight, which is known to inactivate SARS-CoV-2 [17].

Much of the published experimentation on droplet drying [33] has made use of simplified analogues of the respiratory fluids in which viruses are emitted by breathing, speaking, singing, coughing or sneezing. Sometimes just $\mathrm{NaCl}$ solutions have been used. The detailed salt composition of natural aerosols has a profound effect on their drying behaviour [23]. Metzger et al. [31] give an accessible description of the underlying physics (Kohler theory) as an appendix: their nomenclature is adopted here. In respiratory droplets, proteins and glycoproteins have been recognised to contribute volume and mass to the dried droplet nuclei, but little attention has been paid to other ways in which these polymers might influence the drying process $[33,37]$.

Because of the very high salt and polymer concentrations that can be reached when biological aerosols dry at low $\mathrm{RH}$, classical colligative relationships like Raoult's Law become increasingly unsatisfactory approximations and the relevant physical chemistry becomes necessarily more empirical. In these circumstances direct experimental measurements using real biological fluids may be more informative than theoretical prediction [33]. However, these measurements are technically challenging $[33,40]$ and during the pandemic time is short.

This paper describes simulations of the effects of some of the main variables in the composition of virus-containing aerosols on the drying process. Only the drying (efflorescence) direction of RH change is considered, so the focus is on the nucleation-limited quasi-equilibrium with $\mathrm{RH}$ in the region between the efflorescence RH and the deliquescence RH. In view of the uncertainties discussed above, these simulations do not aim at quantitative descriptions of complex, real-life bioaerosols, but may serve to provide some simplifying assumptions and to prioritise variables that deserve experimental investigation. 


\section{Methods}

\section{Modelling mixed $\mathrm{NaCl} / \mathrm{KCl}$ solutions}

Published efflorescence data [41] in the form of measured droplet area ratios $R_{\mathrm{a}}$ with the constant droplet area at $\mathrm{RH}<30 \%$ set as unity, were converted to volume ratios $R_{\mathrm{v}}=R_{\mathrm{a}}^{3 / 2}$. This approach was justified by a close match $( \pm<1 \%)$ with the efflorescence and deliquescence RH measured at bulk scale [41]. For RH below the efflorescence point $R_{\mathrm{v}}=R_{0}$. To obtain absolute salt concentrations the $R_{\mathrm{v}}$ scale needs to be calibrated. The calibration was attempted in three different ways (1-3).

(1) For RH above the efflorescence point $R_{\mathrm{v}}$ is equivalent to the growth factor as conventionally defined [31]. $R_{0}$ was converted to mass using a solid density $\rho_{\text {solid }}$ interpolated between the densities of $\mathrm{KCl}\left(1980 \mathrm{Kgm}^{-3}\right)$ and $\mathrm{NaCl}\left(2176 \mathrm{Kgm}^{-3}\right)$ according to the molar ratio, with a correction factor of 0.6 to account for void volume in the polycrystalline salt deposits. Solution concentrations were then calculated as $R_{0} . \rho_{\text {solid }}\left(R_{\mathrm{v}}-1\right)$.

(2) The ion activity coefficients were calculated from an exponential function of the form $a \cdot \exp \cdot(-b \cdot$ [salt] $)+c$. [salt] $+d$ where $a, b, c$ and $d$ are empirical constants, fitted to activity coefficient data for solutions of the pure salts [42]. The solute activity coefficient at the highest measured RH was input into Raoult's Law to calculate the equilibrium salt concentration at that $\mathrm{RH}$, assuming that the effects of $\mathrm{NaCl}$ and $\mathrm{KCl}$ were additive. Method (2) includes a term for the density of the solutions, which was calculated from an empirical function of the form: $b$ [salt $]^{2}+c$ [salt $]+d$ where the constants $b, c$ and $d$ were derived by least-squares fitting to published data [43] interpolated between $\mathrm{NaCl}$ and $\mathrm{KCl}$.

(3) At the deliquescence RH for a pure salt the solution concentration is equal to the known saturation concentration. For the mixed $\mathrm{NaCl} / \mathrm{KCl}$ solutions for which experimental data [41] were used, deliquescence is a twostage process with a eutonic mixture $(\mathrm{K}$ mol fraction $=0.3)$ dissolving first as the $\mathrm{RH}$ rises, and the excess salt remaining solid. For $(\mathrm{K}$ mol fraction $=0.2)$, therefore, the upper deliquescence RH of 74.2\% [41] was considered to correspond to the solubility of $\mathrm{NaCl}(6.2 \mathrm{~mol} / \mathrm{Kg})$ and for $(\mathrm{K}$ mol fraction $=0.8)$ the upper deliquescence $\mathrm{RH}$ of $79.0 \%$ [26] was considered to correspond to the solubility of $\mathrm{KCl}(5.5 \mathrm{~mol} / \mathrm{Kg})$. This approach is similar to that advocated by Metzger et al. [31].

Calibration methods (1) and (2), which incorporate considerable uncertainties about the shape and density of the dried particles at $\mathrm{RH}$ below the efflorescence $\mathrm{RH}$, the density of concentrated salt solutions and the additivity of the salt effects in aerosols, gave higher concentrations than method (3). Due to these uncertainties method (3) was used in preference.

The Kelvin term in the predicted drying equilibrium was calculated as a function of droplet diameter using the relationship

$\mathrm{RH}=a_{\mathrm{w}} \cdot K_{\mathrm{e}}=a_{\mathrm{w}} \cdot \exp \left(4 M_{\mathrm{w}} \sigma_{\mathrm{sol}} /\left(R T \rho_{\mathrm{w}} D_{\mathrm{wet}}\right)\right.$

where $M_{\mathrm{w}}$ is the molar mass of water, $\rho_{\mathrm{w}}$ is its density and $\sigma_{\mathrm{sol}}$ is the surface tension of the solution [31].

To model water activity in macromolecular solutions, an empirical relationship of osmotic pressure to polymeric solids content (proteins plus glycoproteins) of airway mucus, above and below the sol-gel transition, was derived from the measurements of osmotic pressure in ref. [44].

$\Pi=k c\left[1+(c / c *)^{(\beta-1) m}\right]^{1 / m}$

where $c$ is the mucus polymeric solids concentration $(\mathrm{Kg} / \mathrm{L})$, $c^{*}=0.081 \mathrm{Kg} / \mathrm{L}, m=3, \beta=2.21$ and $k=14.4 \mathrm{KPa} \mathrm{L} / \mathrm{Kg}$.

The water activity of protein/glycoprotein solutions without salt was calculated from the osmotic pressure using the following form of the Van t'Hoff relationship [45]:

Osmotic pressure $\Pi=-R T \ln \left(a_{\mathrm{w}}\right) / V_{\mathrm{w}}$ Rearranging, $a_{\mathrm{w}}=\exp \left(-\Pi V_{\mathrm{w}} / R T\right)$

where $\mathrm{RH}$ is expressed as a fraction, $R$ is the gas constant, $T$ is absolute temperature and $V_{\mathrm{w}}$ is the molar volume of water.

All simulations were carried out in Microsoft Excel, using the SOLVER function for least-squares fitting. The .xlsx files are available from the author on request.

\section{Results}

\section{Origins and composition of emitted droplets}

Aerosols and larger droplets emitted during breathing [40], speech [46], coughing [47] and other activities [48] originate by aerodynamic disruption of the mucosal lining [49] in different zones in the respiratory tract [50,51], leading to different droplet size distributions [52]. The principal zones in which droplets are generated are the bronchioli (modal droplet diameter 1-2 $\mu \mathrm{m}$ ) the laryngeal region (modal droplet diameter 1-2 $\mu \mathrm{m}$ ), and the oral cavity and nasal region (modal droplet diameter $>100 \mu \mathrm{m}$ ) [52]. Multiple sites of origin lead to bimodal, trimodal or broad continuous ranges of droplet diameter for each mode of emission [52]. With droplet diameters covering several orders of magnitude, 
caution is needed in the interpretation of modal figures because they may be derived by several experimental methods with differing size limitations [52] and because numberweighted and volume-weighted distributions are very different: volume-weighted distributions are more relevant to viral load [37].

Droplets emitted in normal breathing are primarily from the bronchial zone and have diameters in the submicron to $\mu \mathrm{m}$ range $[52,53]$, while droplets emitted in talking or coughing are derived partly from the laryngeal and oral zones, with a preponderance of larger particles [50, 52]. The viral load of the mucosa in each region $[54,55]$ varies with disease progression and between individuals [46].

The drying of emitted droplets depends on their ionic and polymer composition. It has not been well recognised that the composition of the droplets differs according to their site of origin [33], and therefore also differs with droplet diameter. A key function of the airway lining throughout the respiratory tract is to sustain hydration [56] and freedom of motion for the underlying cilia [44], defects in hydration leading to disorders such as cystic fibrosis [57]. Equilibrium hydration depends on osmolytes in a very similar way to water retention by emitted droplets [56], although the RH within the respiratory system is much higher. The cation composition of the airway surface liquid is dominated by sodium, with $\mathrm{Na}^{+}: \mathrm{K}^{+}$molar ratios typically around 4:1 [57-59]: the precision is lower for $\mathrm{K}^{+}$than $\mathrm{Na}^{+}$due to the difficulty of sampling without cellular damage [60]. The principal anion is $\mathrm{Cl}^{-}$, with a much smaller amount of $\mathrm{HCO}_{3}{ }^{-}[57,58]$. In health the total osmolarity is approximately $300 \mathrm{mM}$ [58], increasing from the lower respiratory tract to the nasal region [57] and increasing substantially in conditions such as chronic bronchitis [56]. Fluid harvested from human bronchial epithelial (HBE) cell cultures is rather similar in ionic composition to native airway fluids but with lower protein content [59].

In contrast, saliva has much lower ion concentrations and osmolarity. In the normal (resting) state, the total osmolarity averages $50 \mathrm{mM}$ and the main cation is $\mathrm{K}^{+}$with a $\mathrm{K}^{+}: \mathrm{Na}^{+}$ ratio of about 3:1 [61]. The main anion is $\mathrm{Cl}^{-}$. On stimulation, water secretion is driven by an increase in $\mathrm{Na}^{+}$and $\mathrm{Cl}^{-}$concentrations. The $\mathrm{Na}^{+}: \mathrm{K}^{+}$ratio is therefore variable and can exceed unity [61]. The large difference in salt concentrations between saliva and airway surface fluids means that sputum varies in composition between these extremes [59]. Similarly, emitted droplets are predicted to have an overall $\mathrm{K}^{+}: \mathrm{Na}^{+}$ratio that depends on the saliva contribution and is highest for speech [52], whereas the aerosol droplets emitted by breathing originate mainly from the lining of the lower respiratory tract and are dominated by $\mathrm{Na}^{+}$. In emissions of mixed origin, large droplets [52] are likely to be dominated by $\mathrm{K}^{+}$and small droplets [52] by $\mathrm{Na}^{+}$, leading to differences in their evaporation equilibria.

\section{Simulated effects of $\mathrm{Na}^{+}: \mathrm{K}^{+}$ratio}

$\mathrm{KCl}$ is less hygroscopic than $\mathrm{NaCl}$ [41]. Therefore, neglecting the direct (Kelvin) effect of droplet size, large droplets with $\mathrm{KCl}$ as the predominant salt would be predicted to reach their efflorescence point at higher RH than small droplets with $\mathrm{NaCl}$ as the predominant salt.

However, the behaviour of salt mixtures is not necessarily additive. Li et al. [41] measured droplet sizes of mixed $\mathrm{KCl}: \mathrm{NaCl}$ aerosols as they increased with increasing $\mathrm{RH}$ and decreased with decreasing $\mathrm{RH}$, using a microscopy technique after impaction. Figure 1, calculated from the experimental data of Li et al. [41], shows that in aerosol mixtures of $\mathrm{KCl}$ and $\mathrm{NaCl}$, with no other solutes present, the relationship of the minimum water activity at the efflorescence $\mathrm{RH}$ to the K:Na ratio is non-linear, with the lowest values reached at about $\mathrm{K}$ mol fraction 0.4 . Thus each salt tends to keep the other in solution until both precipitate together at the efflorescence RH.

Figure 2 shows that In the absence of other solutes, mixtures of $\mathrm{NaCl}$ and $\mathrm{KCl}$ can reach concentrations up to $13 \mathrm{~mol} / \mathrm{Kg}$, much greater than their nominal solubility. Such high concentrations have been suggested to reduce survival of susceptible viruses [21]. Somewhat higher maximal salt concentrations are reached, at lower $\mathrm{RH}$, when the major cation is sodium, mainly because $\mathrm{NaCl}$ is more soluble than $\mathrm{KCl}$. When the $\mathrm{RH}$ fell below the efflorescence point each droplet contracted abruptly to an irregular solid that remained constant in size down to $\mathrm{RH}=5 \%$ [41], from which it was assumed that the liquid phase disappeared at the efflorescence RH. The mixture with $\mathrm{K}$ mol fraction 0.2 is representative of the principal ion content of airway lining fluid [57, 58] emitted mainly as small $(<10 \mu \mathrm{m})$ droplets [52]. The mixture with $\mathrm{K}$ mol fraction 0.8 is representative of the principal ion

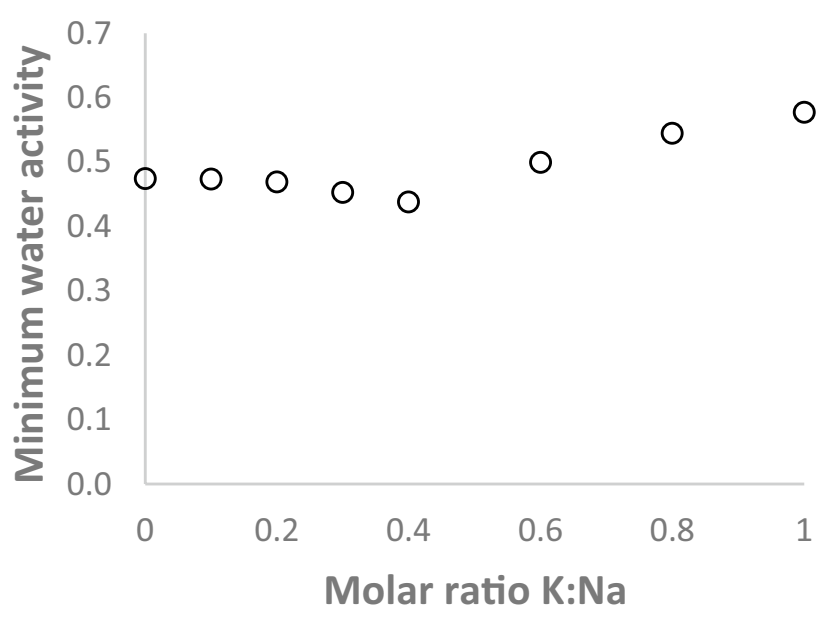

Fig. 1 Minimum water activity, at the efflorescence $\mathrm{RH}$, of $\mathrm{KCl}$ : $\mathrm{NaCl}$ mixtures in aerosol form. Calculated from data in [41] 


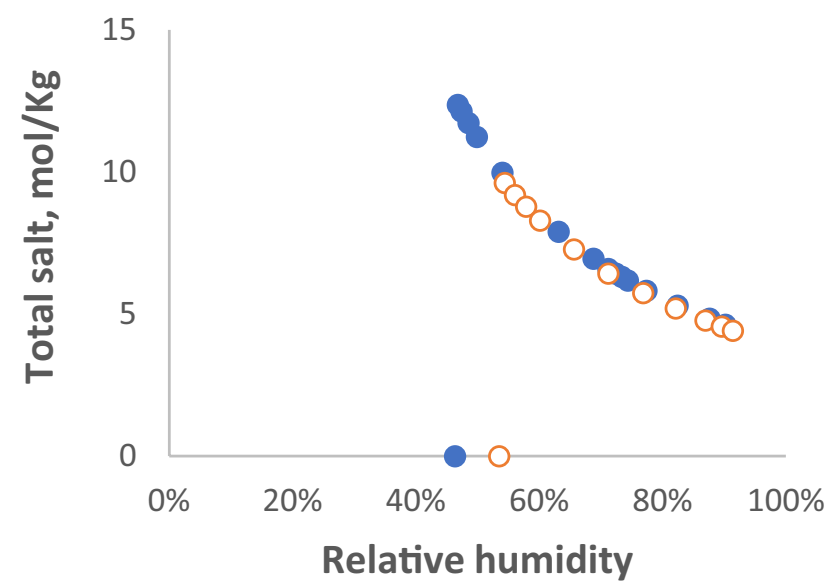

Fig. 2 Simulated total salt concentration in aerosols of $\mathrm{KCl} / \mathrm{NaCl}$ mixtures as a function of decreasing relative humidity, calculated from [41]. Salt concentrations increased as the droplets dried until they reached a maximum at the efflorescence RH. Below the efflorescence $\mathrm{RH}$, with the salts precipitated the droplets dried abruptly

content of saliva [61] emitted mainly as larger $(>10 \mu \mathrm{m})$ droplets [52]. Ions other than $\mathrm{Na}^{+}$and $\mathrm{K}^{+}$are also present, of course, and their contribution to drying equilibria could be calculated [23] if comprehensive consensus values for their concentrations were available.

\section{Droplet diameter: The Kelvin effect}

The extent to which droplets dry at any RH is also influenced directly by their size due to the Kelvin effect. The increased surface curvature of small droplets leads to the diameterdependent Kelvin term $K_{\mathrm{e}}$ in the expression for their drying equilibrium [31].

Figure 3 shows that the effect of including the Kelvin term in the simulation is to displace the whole curve to higher RH. The Kelvin effect starts to become significant only at droplet diameters below about $0.1 \mu \mathrm{m}$. In calculating the Kelvin term it is generally assumed that the droplet is wholly liquid and is spherical [31]. When a mixture of irregular solid and liquid phases is present, the local radius at protuberances may be less than calculated and the effect augmented.

The magnitude of the Kelvin effect depends also on $\sigma_{\text {sol }}$, the surface tension, which in the simulation above was assumed constant and equivalent to that of water. However, surfactants reduce $\sigma_{\mathrm{sol}}$, [62] and are present in airway surface liquids [63], influencing their fragmentation into aerosols [49]. Surfactant proteins [63] are best known from the lungs but are detectable elsewhere [64] and are accompanied by deacylated phosphatidyl choline [65]. The effect of surfactants on biogenic droplet drying has not been quantified

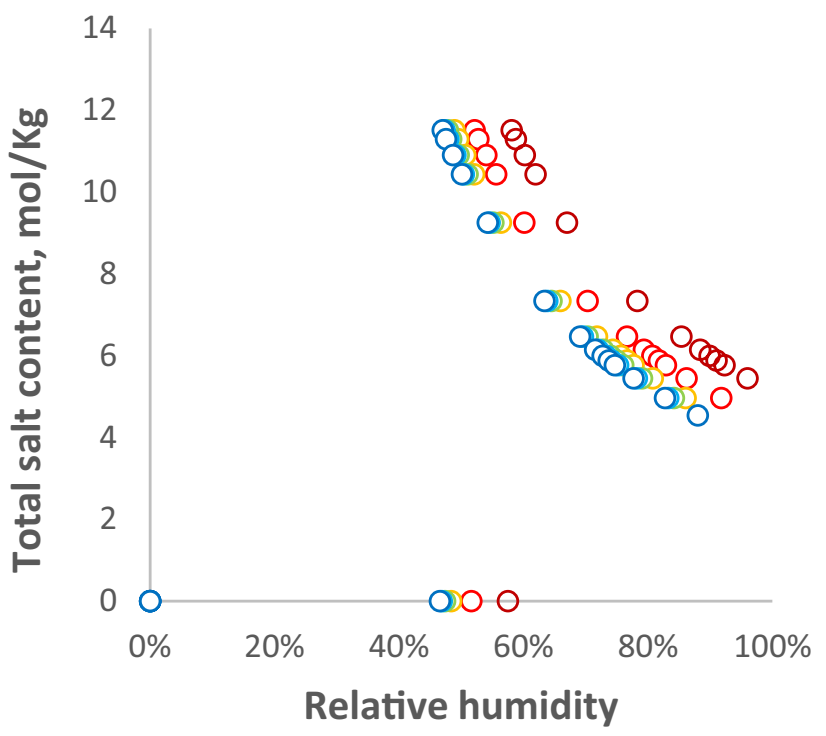

Droplet diameter, $\mu \mathrm{m}$

$\begin{array}{llllll}0.01 & 00.02 & 00.05 & 00.1 & 00.2 & 00.5\end{array}$

Fig. 3 Simulated effect of droplet diameter, through inclusion of the Kelvin term, on the equilibrium salt molality during drying of aerosol droplets with $\mathrm{K}$ mol fraction $=0.2$ as in Fig. 2

but it can be assumed that they reduce the magnitude of the Kelvin term, to an uncertain and possibly large extent [62].

\section{Macromolecular composition: Proteins and mucin glycoproteins}

Figure 2 simulates the drying of $\mathrm{NaCl} / \mathrm{KCl}$ mixtures with no other solutes present. Virus-containing aerosols contain larger amounts of proteins and glycoproteins [59, 61], which increase in concentration as the droplets dry until they constitute most of the mass of the droplet nucleus. It is often assumed that these macromolecules have no influence on water activity [34], an assumption that might not be valid when the amount of protein is comparable with the amount of remaining water.

In the intact airway lining, mucin glycoproteins have been stated to play a role in maintaining hydration [56] and have been studied with that function in mind [59]. Reduced water content and increased viscosity are well-known factors in cystic fibrosis and other pathological conditions [56, 59]. A substantial rheological change attributed to gelation has been observed when the solids content or mucin content of normal airway fluid is doubled [59], which would occur at $\mathrm{RH}>90 \%$ during droplet drying. It would then follow that during much of the hysteresis part of the aerosol drying curve the mucin fraction, and perhaps other proteins, are in the gel state. Osmotic relations of polymer gels are difficult to handle, although for simplification it is often assumed that 
only low-molecular species - free salts and the counterions associated with any charges on the polymer - contribute to lowering water activity [66]. This assumption may not hold at high polymer concentrations or for very flexible polymers that undergo vigorous segmental motion.

In the case of airway fluid, these conceptual problems have been circumvented by direct measurement of the polymer-associated osmotic pressure using a membrane permeable to salts that are not associated with the polymer $[44,56]$.

Water activity $a_{\mathrm{w}}$, and hence equilibrium relative humidity, was calculated from the osmotic pressure using an appropriate form of the Van t'Hoff relationship [45].

Figure 4 compares (a) the reduction in water activity due to the salts, calculated (without including the Kelvin term) from the RH data of Li et al. [41], with (b) the reduction in water activity due to proteins and glycoproteins calculated from the osmotic pressure data of Button et al. [44] when solutions with ionic and protein/glycoprotein content representative of airway fluid were dried as far as equilibrium with $71 \%$ RH. Drying to this extent requires extrapolation of the osmotic pressure data somewhat beyond the measured protein concentration range [44]. Within the concentration range shown, the contribution of the protein and glycoprotein fraction to the reduction in water activity was two orders of magnitude lower than the contribution of the salt mixture, and so would for many purposes be negligible. Extrapolation further into the concentration range where the mucin

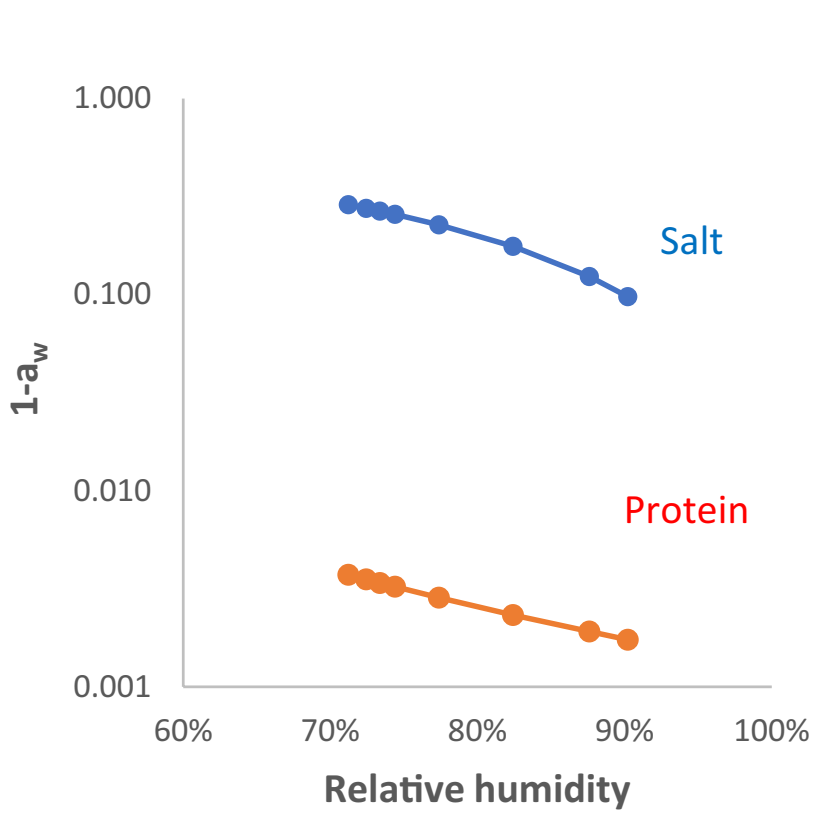

Fig. 4 Simulated reduction in water activity $a_{\mathrm{w}}$, i.e. $\left(1-a_{\mathrm{w}}\right)$, during drying of airway surface liquid, by the influence of salt, calculated from $\mathrm{RH}$ data for a $\mathrm{NaCl} / \mathrm{KCl}$ mixture with initial total salt concentration $150 \mathrm{mM}$ and $\mathrm{K}^{+}: \mathrm{Na}^{+}$molar ratio 0.2 (see Fig. 2); and by the influence of the macromolecular (protein and glycoprotein) fraction, calculated from the osmotic pressure measurements of ref. [44]. Note that the $\left(1-a_{\mathrm{w}}\right)$ scale is logarithmic components gel would be unsafe, bearing in mind the complexity of the osmotic properties of biomacromolecule gels.

To explore what might happen at lower RH, Fig. 5 shows the remaining moisture relative to the mass of protein and glycoprotein (approximated as total solids $-(\mathrm{NaCl}+\mathrm{KCl})$ ) for compositions representative of airway fluid [59] ( $0.2 \mathrm{~mol}$ fraction $\mathrm{K}, 40 \mathrm{~g} / \mathrm{L}$ total solids) and saliva [61] (0.8 mol fraction $\mathrm{K}, 5 \mathrm{~g} / \mathrm{L}$ total solids). The extent of drying was calculated from the salt content only, neglecting the hygroscopic effect of the polymer fraction. The simulated moisture curves for solutions representing airway fluid and saliva remained above $25 \%$ until the efflorescence point was reached. In general proteins at less than $20 \%$ moisture form hydrated solids, with the water in adsorbed form retained quite strongly to low RH and no separate liquid phase [67]. This would be expected to happen below the efflorescence point.

\section{Discussion}

The barrier to nucleation of salt precipitation (efflorescence) in aerosol particles means that simple salt mixtures can potentially reach very high concentrations in a rather narrow mid-range band of RH values just above the efflorescence point [12]. Below the efflorescence $\mathrm{RH}$ the salts precipitate and no longer retain water (Fig. 2). It should be noted than

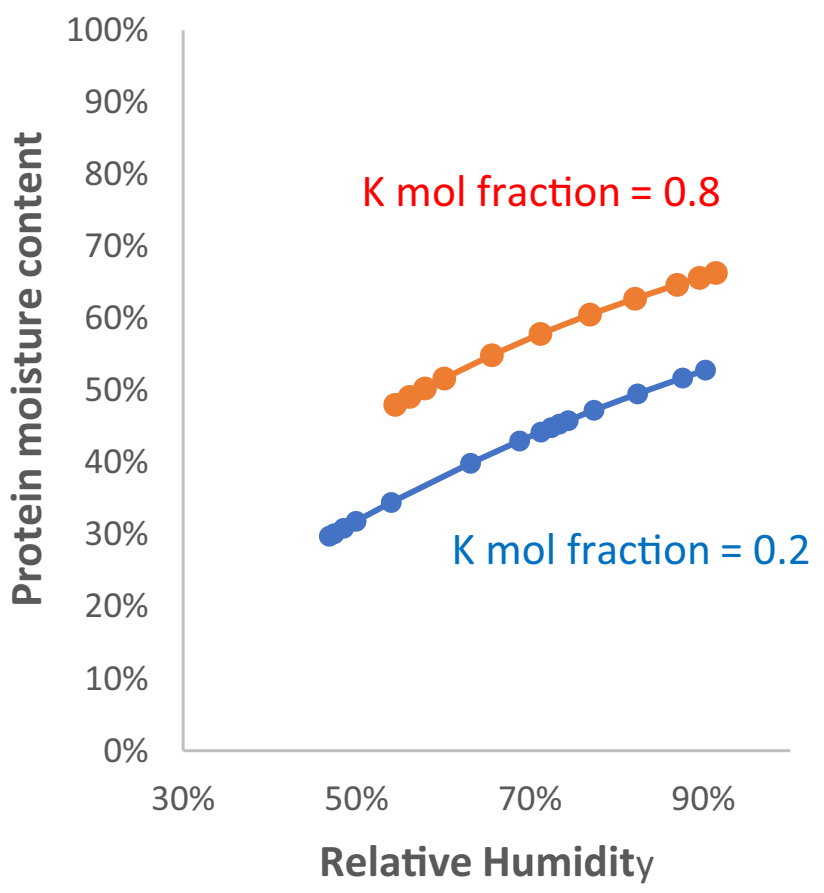

Fig. 5 Residual moisture content of the protein and glycoprotein fraction for solutions simulating airway surface liquid (Initial solids $40 \mathrm{~g} / \mathrm{L}$; Initial salt $0.15 \mathrm{~mol} / \mathrm{L} ; \mathrm{K}$ mol fraction=0.2) and saliva (Initial solids $5 \mathrm{~g} / \mathrm{L}$; Initial salt $0.027 \mathrm{~mol} / \mathrm{L} ; \mathrm{K}$ mol fraction=0.8) during drying 
anything that can nucleate crystallisation will lead to a lower maximal salt concentration, at higher RH than the nominal efflorescence point. Examples of potential nucleating influences are surfaces [68], precipitated proteins, or solid particles from pollution aerosols [69]. The statistical likelihood of nucleation is greater in larger volumes of solution. Realworld aerosol droplets [25] are therefore likely to show less extreme behaviour than simple salt mixtures. While model airway fluids $[22,29]$ showed clear efflorescence-deliquescence hysteresis, hysteresis was variable in cough aerosols from different individuals and was not evident in aerosols from some subjects [25].

In artificial media, in both aerosol form [20-22] and as surface deposits [29], several viruses are inactivated faster in the intermediate RH region where hysteresis is observed, compared with low or high RH. Suggested mechanisms include the direct effect of elevated salt concentration [29]; the removal of structural water [20]; the disruption of hydrophobic bonding at low water activity [30] and changes in $\mathrm{pH}$ $[20,70]$. Abrupt changes in hydration may be more disruptive than gradual changes [22]. Inactivation is particularly slow when droplets dry onto non-porous surfaces [71-73], for reasons that are not clear: water activity in surface deposits depends on ambient $\mathrm{RH}$ in the same way as in aerosol droplets large enough for the Kelvin effect to be ignored. Fractionation of solutes during surface drying [70, 74, 75] might lead to salt-free areas where the virus can survive in dried form at higher $\mathrm{RH}$, or inactivation may occur at the air-water interface [76] or due to local capillary forces [77]. There is a potential parallel in the viability of viruses sorbed on atmospheric particulates [37].

The nature of the cations present in virus-containing emitted droplets deserves closer attention, since the ionic composition of saliva [61] differs from that of airway fluids [59]. The low salt content and high proportion of $\mathrm{KCl}$ in saliva droplets means that their maximal salt content is reached at higher RH than for Na-rich airway fluids. Although a salivarich cough [52] and a sneeze [48] emit droplets with rather similar initial size ranges, their drying behaviours are predicted to differ.

The dependence of drying equilibrium on droplet size through the Kelvin effect becomes noticeable when the liquid droplet diameter is less than $0.1 \mu \mathrm{m}$ (Fig. 3). Diameter distributions on emission by normal breathing include large numbers of droplets $<0.1 \mu \mathrm{m}$ [52]. However, the volume-weighted diameter distributions, which are more relevant to viral load, include only a small fraction of $<0.1 \mu \mathrm{m}$ droplets, even for breathing [37]. Also, the magnitude of the Kelvin effect is reduced to an unknown extent [62] by the presence of pulmonary and other surfactants. Thus, for many purposes it is a reasonable assumption to neglect the Kelvin term in drying simulations. This prediction has practical consequences. Variations in drying equilibria with droplet size are more likely to arise from differences in site of origin and composition, rather than from the Kelvin effect. Usefully, experiments on the hygroscopic properties of bulk biological fluids, e.g. measurements of osmotic pressure $[44,56]$, are relevant to the behaviour of aerosols so that in suitable cases, it may be possible to obtain usable experimental data without the technical challenges inherent in aerosol generation and measurement.

However it may be inadvisable to neglect the Kelvin effect for partially dried particles or surface deposits where polycrystalline salts are present, because liquid films may have small local radii overlying crystal vertices and negative (inward) radii in interstices, leading to variation in local water activity.

In the drying range up to about $20 \%$ solids content, the hygroscopic effect of proteins and of glycoproteins such as mucins is predicted to be negligible in comparison with the effect of the salts present (Fig. 4). Below the efflorescence RH the macromolecular fraction is likely to be essentially an amorphous solid holding any remaining water quite strongly (Fig. 5). In the $40 \%-80 \%$ solids range the mucin fraction at least is likely to form a gel, within which water relations are difficult to predict [66]. Other, salted-out proteins are likely to be interspersed with the mucin glycoproteins and protein aggregates may act as nucleation points for salt precipitation above the efflorescence RH. In this region of complex physical chemistry, experiments on real biological fluids may be a better guide to the behaviour of the system than available theory.

It is concluded that the drying equilibria of aerosol and larger droplets containing infectious viruses are determined principally by the salt composition of the droplets. The salts present in saliva are $\mathrm{K}^{+}$-dominated, whereas the more concentrated salts present in airway surface liquids are $\mathrm{Na}^{+}$-dominated and, in the absence of other solutes, precipitate (effloresce) at lower RH. These differences mean that droplets emitted by breathing, speech, coughing and sneezing differ in drying behaviour according to their site of origin and that in emissions with multiple sites of origin, drying behaviour differs between small and large droplets.

Funding The research described in this paper was not supported by any funding body.

Data availability Excel spreadsheets deriving the numerical data presented are available on request from the author.

Code availability See above. 


\section{Declarations}

Conflicts of interest/Competing interests The author declares no competing or conflicting interest.

Open Access This article is licensed under a Creative Commons Attribution 4.0 International License, which permits use, sharing, adaptation, distribution and reproduction in any medium or format, as long as you give appropriate credit to the original author(s) and the source, provide a link to the Creative Commons licence, and indicate if changes were made. The images or other third party material in this article are included in the article's Creative Commons licence, unless indicated otherwise in a credit line to the material. If material is not included in the article's Creative Commons licence and your intended use is not permitted by statutory regulation or exceeds the permitted use, you will need to obtain permission directly from the copyright holder. To view a copy of this licence, visit http://creativecommons.org/licenses/by/4.0/.

\section{References}

1. Pohlker ML, Kruger OO, Forster J-D, Elbert W, Frohlich-Nowoisky J, Poschl U, et al. Respiratory aerosols and droplets in the transmission of infectious diseases. ArXiv. 2021:1-46. arXiv: 2103.01188

2. Fenelly KP. Particle sizes of infectious aerosols: implications for infection control. Lancet Respiratory Medicine. 2020;8:914-24. https://doi.org/10.1016/S2213-2600(20)30323-4.

3. Tang JW. The effect of environmental parameters on the survival of airborne infectious agents. J R Soc Interface. 2009;6:S737-46. https://doi.org/10.1098/rsif.2009.0227.focus.

4. Tang JW, Bahnfleth WP, Bluyssen PM, Buonanno G, Jimenez JL, Kurnitski J, et al. Dismantling myths on the airborne transmission of severe acute respiratory syndrome coronavirus (SARS-CoV-2). J Hospital Infect. 2021;110:89-96. https://doi.org/10.1016/j.jhin. 2020.12.022

5. Bourouiba L, Dehandschoewercker E, Bush JWM. Violent expiratory events: on coughing and sneezing. J Fluid Mech. 2014;745:537-63. https://doi.org/10.1017/jfm.2014.88.

6. Choi JI, Edwards JR. Large-eddy simulation of human-induced contaminant transport in room compartments. Indoor Air. 2012;22:77-87. https://doi.org/10.1111/j.1600-0668.2011.00741.

7. Sun S, Li J, Han J. How human thermal plume influences nearhuman transport of respiratory droplets and airborne particles: a review. Environ Chem Lett. 2021:1-12. https://doi.org/10.1007/ s10311-020-01178-.

8. Dancer SJ, Tang JW, Marr LC, Miller S, Morawska L, Jimenez JL. Putting a balance on the aerosolization debate around SARSCoV-2. J Hosp Infect. 2020;105:569-70. https://doi.org/10.1016/j. jhin.2020.05.014.

9. Meyerowitz EA, Richterman A, Gandhi RT, Sax PE. Transmission of SARS-CoV-2: a review of viral, host, and environmental factors. Ann Intern Med. 2021;174:69-79. https://doi.org/10.7326/ m20-5008

10. Lipinski T, Ahmad D, Serey N, Jouhara H. Review of ventilation strategies to reduce the risk of disease transmission in high occupancy buildings. Int J Thermofluids. 2020;7:100045. https://doi. org/10.1016/j.ijft.2020.100045.

11. Sun $C, Z$ Zhai $Z$. The efficacy of social distance and ventilation effectiveness in preventing COVID-19 transmission. Sustain Cities Soc. 2020;62:102390. https://doi.org/10.1016/j.scs.2020.102390.

12. Niazi S, Groth R, Spann K, Johnson GR. The role of respiratory droplet physicochemistry in limiting and promoting the airborne transmission of human coronaviruses: a critical review. Environ Pollut. 2021;276:115767. https://doi.org/10.1016/j.envpol.2020. 115767.

13. Smither SJ, Eastaugh LS, Findlay JS, Lever MS. Experimental aerosol survival of SARS-CoV-2 in artificial saliva and tissue culture media at medium and high humidity. Emerging Microb Infect. 2020;9:1415-7. https://doi.org/10.1080/22221751.2020. 1777906.

14. Ren S-Y, Wang W-B, Hao Y-G, Zhang H-R, Wang Z-C, Chen Y-L, et al. Stability and infectivity of coronaviruses in inanimate environments. World J Clin Cases. 2020;8:1391-9. https://doi.org/ 10.12998/wjcc.v8.i8.1391.

15. van Doremalen N, Bushmaker T, Morris DH, Holbrook MG, Gamble A, Williamson BN, et al. Aerosol and surface stability of SARS-CoV-2 as compared with SARS-CoV-1. N Engl J Med. 2020;382:1564-7. https://doi.org/10.1056/NEJMc2004973.

16. Fears AC, Klimstra WB, Duprex P, Hartman A, Weaver SC, Plante $\mathrm{KS}$, et al. Persistence of severe acute respiratory syndrome coronavirus 2 in aerosol suspensions. Emerg Infect Dis. 2020;26. https:// doi.org/10.3201/eid2609.201806.

17. Dabisch P, Schuit M, Herzog A, Beck K, Wood S, Krause M, et al. The influence of temperature, humidity, and simulated sunlight on the infectivity of SARS-CoV-2 in aerosols. Aerosol Sci Technol. 2021;55:142-53. https://doi.org/10.1080/02786826.2020.18295 36.

18. Chin AWH, Chu JTS, Perera MRA, Hui KPY, Yen H-L, Chan MCW, et al. Stability of SARS-CoV-2 in different environmental conditions. Lancet Microb. 2020;1:e10. https://doi.org/10.1016/ S2666-5247(20)30003-3.

19. Beggs CB, Avital EJ. Psychrometric model to assess the biological decay of the SARS-CoV-2 virus in aerosols. PeerJ. 2021;9:e11024. https://doi.org/10.7717/peerj.11024.

20. Yang W, Marr LC. Mechanisms by which ambient humidity may affect viruses in aerosols. Appl Environ Microbiol. 2012;78:67818. https://doi.org/10.1128/aem.01658-12.

21. Niazi S, Groth R, Cravigan L, He C, Tang JW, Spann K, et al. Susceptibility of an airborne common cold virus to relative humidity. Environ Sci Technol. 2021;55:499-508. https://doi.org/10.1021/ acs.est.0c06197.

22. Niazi S, Short KR, Groth R, Cravigan L, Spann K, Ristovski $\mathrm{Z}$, et al. Humidity-dependent survival of an airborne influenza a virus: practical implications for controlling airborne viruses. Environ Sci Technol Lett. 2021;8:412-8. https://doi.org/10.1021/ acs.estlett.1c00253.

23. Metzger S, Steil B, Abdelkader M, Klingmuller K, Xu L, Penner JE, et al. Aerosol water parameterisation: a single parameter framework. Atmos Chem Phys. 2016;16:7213-37. https://doi.org/ 10.5194/acp-16-7213.

24. Davies JF, Price CL, Choczynski J, Kohli RK. Hygroscopic growth of simulated lung fluid aerosol particles under ambient environmental conditions. Chem Commun. 2021;57:3243-6. https://doi.org/10.1039/d1cc00066g.

25. Groth R, Cravigan LT, Niazi S, Ristovski Z, Johnson GR. In situ measurements of human cough aerosol hygroscopicity. J R Soc Interface. 2021;18:20210209. https://doi.org/10.1098/rsif.2021. 0209.

26. Schuit M, Ratnesar-Shumate S, Yolitz J, Williams G, Weaver W, Green B, et al. Airborne SARS-CoV-2 is rapidly inactivated by simulated sunlight. J Infect Dis. 2020;222:564-71. https://doi.org/ 10.1093/infdis/jiaa334.

27. Marques M, Domingo JL. Contamination of inert surfaces by SARS-CoV-2: persistence, stability and infectivity. A review. Environ Res. 2021;193:110559. https://doi.org/10.1016/j.envres. 2020.110559.

28. Guillier L, Martin-Latil S, Chaix E, Thebault A, Pavio N, Le Poder S, et al. Modeling the inactivation of viruses from the 
Coronaviridae family in response to temperature and relative humidity in suspensions or on surfaces. Appl Environ Microbiol. 2020;86. https://doi.org/10.1128/aem.01244-20.

29. Morris DH, Yinda KC, Gamble A, Rossine FW, Huang Q, Bushmaker $\mathrm{T}$ et al. Mechanistic theory predicts the effects of temperature and humidity on inactivation of SARS-CoV-2 and other enveloped viruses. eLife 2021; 10. https://doi.org/10.7554/eLife. 65902.

30. Bormashenko E, Fedorets AA, Dombrovsky LA, Nosonovsky M. Survival of virus particles in water droplets: hydrophobic forces and Landauer's principle. Entropy. 2021;23:181. https://doi.org/ 10.3390/e23020181.

31. Metzger S, Steil B, Xu L, Penner JE, Lelieveld J. New representation of water activity based on a single solute specific constant to parameterize the hygroscopic growth of aerosols in atmospheric models. Atmos Chem Phys. 2012;12:5429-46. https://doi.org/10. 5194/acp-12-5429-2012.

32. Bueckert M, Gupta R, Gupta A, Garg M, Mazumder A. Infectivity of SARS-CoV-2 and other coronaviruses on dry surfaces: potential for indirect transmission. Materials. 2020;13:5211. https://doi. org/10.3390/ma13225211.

33. Lieber C, Melekidis S, Koch R, Bauer H-J. Insights into the evaporation characteristics of saliva droplets and aerosols: levitation experiments and numerical modeling. J Aerosol Sci. 2021;154:105760. https://doi.org/10.1016/j.jaerosci.2021.105760.

34. Liu L, Wei J, Li Y, Ooi A. Evaporation and dispersion of respiratory droplets from coughing. Indoor Air. 2017;27:179-90. https:// doi.org/10.1111/ina.12297.

35. Chong KL, Ng CS, Hori N, Yang R, Verzicco R, Lohse D. Extended lifetime of respiratory droplets in a turbulent vapor puff and its implications on airborne disease transmission. Phys Rev Lett. 2021;126:034502. https://doi.org/10.1103/PhysRevLett.126. 034502.

36. Yang X, Ou C, Yang H, Liu L, Song T, Kang M, et al. Transmission of pathogen-laden expiratory droplets in a coach bus. $\mathrm{J}$ Hazard Mater. 2020;397:122609. https://doi.org/10.1016/j.jhazm at.2020.122609.

37. Jarvis MC. Aerosol transmission of SARS-CoV-2: physical principles and implications. Frontiers Public Health. 2020;590041. https://doi.org/10.3389/fpubh.2020.590041.

38. Lin K, Schulte CR, Marr LC. Survival of MS2 and phi 6 viruses in droplets as a function of relative humidity, $\mathrm{pH}$, and salt, protein, and surfactant concentrations. PLoS One. 2020;15:0234505. https://doi.org/10.1371/journal.pone.0243505.

39. McDevitt J, Rudnick S, First M, Spengler J. Role of absolute humidity in the inactivation of influenza viruses on stainless steel surfaces at elevated temperatures. Appl Environ Microbiol. 2010;76:3943-7. https://doi.org/10.1128/aem.02674.

40. Johnson GR, Morawska L. The mechanism of breath aerosol formation. J Aerosol Med Pulmon Drug Deliv. 2009;22:229-37. https://doi.org/10.1089/jamp.2008.0720.

41. Li X, Gupta D, Eom H-J, Kim H. Ro C-U deliquescence and efflorescence behavior of individual $\mathrm{NaCl}$ and $\mathrm{KCl}$ mixture aerosol particles. Atmos Environ. 2014;82:36-43. https://doi.org/10. 1016/j.atmosenv.2013.10.011.

42. Scatchard G, Hamer WJ, Wood SE, Isotonic solutions I. The chemical potential of water in aqueous solutions of sodium chloride, potassium chloride, sulfuric acid, sucrose, urea and glycerol at $25^{\circ}$. J Am Chem Soc. 1938;60:3061-70. https://doi.org/10. 1021/ja01279a066.

43. Engineering Toolbox Density of aqueous solutions of inorganic sodium salts, 2020. https://www.engineeringtoolbox.com/densi ty-aqueous-solution-inorganic-sodium-salt-concentration-d_1957. html. Accessed 2 Apr 2021.

44. Button B, Cai L-H, Ehre C, Kesimer M, Hill DB, Sheehan JK, et al. A periciliary brush promotes the lung health by separating the mucus layer from airway epithelia. Science. 2012;337:937-41. https://doi.org/10.1126/science.1223012.

45. Subbiah B, Blank UKM, Morison KR. A review, analysis and extension of water activity data of sugars and model honey solutions. Food Chem. 2020;326:126891. https://doi.org/10.1016/j. foodchem.2020.126981.

46. Asadi S, Wexler AS, Cappa CD, Barreda S, Bouvier NM, Ristenpart WD. Aerosol emission and superemission during human speech increase with voice loudness. Sci Rep. 2019;9:2348. https://doi.org/10.1038/s41598-019-38808-z.

47. Fabian P, Brain J, Houseman EA, Gern J, Milton DK. Origin of exhaled breath particles from healthy and human rhinovirus-infected subjects. J Aerosol Med Pulmon Drug Deliv. 2011;24:137-47. https://doi.org/10.1089/jamp.2010.0815.

48. Han ZY, Weng WG, Huang QY. Characterizations of particle size distribution of the droplets exhaled by sneeze. J R Soc Interface. 2013;10:0560. https://doi.org/10.1098/rsif.2013.0560.

49. Hamed R, Schenck DM, Fiegel J. Surface rheological properties alter aerosol formation from mucus mimetic surfaces. Soft Matter. 2020;16:7823-34. https://doi.org/10.1039/d0sm01232g.

50. Morawska L, Johnson GR, Ristovski ZD, Hargreaves M, Mengersen K, Corbett S, et al. Size distribution and sites of origin of droplets expelled from the human respiratory tract during expiratory activities. J Aerosol Sci. 2009;40:256-69. https:// doi.org/10.1016/j.jaerosci.2008.11.002.

51. Mittal R, Ni R, Seo J-H. The flow physics of COVID-19. J Fluid Mech. 2020;894:F2. https://doi.org/10.1017/jfm.2020.330.

52. Johnson GR, Morawska L, Ristovski ZD, Hargreaves M, Mengersen K, Chao CYH, et al. Modality of human expired aerosol size distributions. J Aerosol Sci. 2011;42:839-51. https://doi.org/10.1016/j.jaerosci.2011.07.

53. Guo Y, Wei J, Ou C, Liu L, Sadrizadeh S, Jin T, et al. Deposition of droplets from the trachea or bronchus in the respiratory tract during exhalation: a steady-state numerical investigation. Aerosol Sci Technol. 2020;54:869-79. https://doi.org/10.1080/ 02786826.2020 .1772459 .

54. Buonanno G, Stabile L, Morawska L. Estimation of airborne viral emission: quanta emission rate of SARS-CoV-2 for infection risk assessment. Environ Int. 2020;141:105794. https://doi. org/10.1016/j.envint.2020.105794

55. Hou YXJ, Okuda K, Edwards CE, Martinez DR, Asakura $\mathrm{T}$, Dinnon $\mathrm{KH}$, et al. SARS-CoV-2 reverse genetics reveals a variable infection gradient in the respiratory tract. Cell. 2020;182:429-46. https://doi.org/10.1016/j.cell.2020.05.

56. Anderson WH, Coakley RD, Button B, Henderson AG, Zeman $\mathrm{KL}$, Alexis NE, et al. The relationship of mucus concentration (hydration) to mucus osmotic pressure and transport in chronic bronchitis. Am J Respir Crit Care Med. 2015;192:182-90. https://doi.org/10.1164/rccm.201412-2230OC.

57. Knowles MR, Robinson JM, Wood RE, Pue CA, Mentz WM, Wager GC, et al. Ion composition of airway surface liquid of patients with cystic fibrosis as compared with normal and disease-control subjects. J Clin Investig. 1997;100:2588-95. https://doi.org/10.1172/jci119802.

58. Jayaraman S, Joo NS, Reitz B, Wine JJ, Verkman AS. Submucosal gland secretions in airways from cystic fibrosis patients have normal $\mathrm{Na}^{+}$and $\mathrm{pH}$ but elevated viscosity. Proc Natl Acad Sci U S A. 2001;98:8119-23. https://doi.org/10.1073/pnas. 131087598.

59. Markovetz MR, Subramani DB, Kissner WJ, Morrison CB, Garbarine IC, Ghio A, et al. Endotracheal tube mucus as a source of airway mucus for rheological study. Am J Phys Lung Cell Mol Phys. 2019;317:L498-509. https://doi.org/10.1152/ajplung.00238.

60. Landry JS, Eidelman DH. Airway surface liquid: end of the controversy? J Gen Physiol. 2001;117:419-22. https://doi.org/10. 1085/jgp.117.5.419. 
61. Kumar B, Nilotpol K, Avinash A, Chevvuri R, Sagar MK, Shrikant $\mathrm{K}$. The composition, function and role of saliva in maintaining oral health: a review. Int J Contemp Dental Med Rev. 2017;011217 https://doi.org/10.15713/ins.ijcdmr.121.

62. Bzdek BR, Reid JP, Malila J, Prisle NL. The surface tension of surfactant-containing, finite volume droplets. Proc Natl Acad Sci U S A. 2020;117:8335-43. https://doi.org/10.1073/pnas.19156 60117.

63. Larsson P, Mirgorodskaya E, Samuelsson L, Bake B, Almstrand A-C, Bredberg A, et al. Surfactant protein a and albumin in particles in exhaled air. Respir Med. 2012;106:197-204. https://doi. org/10.1016/j.rmed.2011.10.008.

64. Schicht M, Stengl C, Sel S, Heinemann F, Gotz W, Petschelt A, et al. The distribution of human surfactant proteins within the oral cavity and their role during infectious diseases of the gingiva. Annals Anatomy-Anatomischer Anzeiger. 2015;199:92-7. https:// doi.org/10.1016/j.aanat.2014.05.040.

65. Larsson P, Bake B, Wallin A, Hammar O, Almstrand A-C, Larstad $\mathrm{M}$, et al. The effect of exhalation flow on endogenous particle emission and phospholipid composition. Respir Physiol Neurobiol. 2017;243:39-46. https://doi.org/10.1016/j.resp.2017.05.003.

66. Komori T, Sakamoto R. On Tanaka-Fillimores kinetics swelling of gels. Colloid Polym Sci. 1989;267:179-83. https://doi.org/10. $1007 / \mathrm{bf01410357.}$

67. Hernandez-Izquierdo VM, Krochta JM. Thermoplastic processing of proteins for film formation - a review. J Food Sci. 2008;73:R309. https://doi.org/10.1111/j.1750-3841.2007.00636.x.

68. Ciobanu VG, Marcolli C, Krieger UK, Zuend A, Peter T. Efflorescence of ammonium sulfate and coated ammonium sulfate particles: evidence for surface nucleation. J Phys Chem A. 2010;114:9486-95. https://doi.org/10.1021/jp103541w.

69. Davis RD, Lance S, Gordon JA, Ushijima SB, Tolbert MA. Contact efflorescence as a pathway for crystallization of atmospherically relevant particles. Proc Natl Acad Sci U S A. 2015;112:15815-20. https://doi.org/10.1073/pnas.1522860113.
70. Vejerano EP, Marr LC. Physico-chemical characteristics of evaporating respiratory fluid droplets. J R Soc Interface. 2018;15:0939. https://doi.org/10.1098/rsif.2017.0939.

71. Marzoli F, Bortolami A, Pezzuto A, Mazzetto E, Piro R, Terregino $\mathrm{C}$, et al. A systematic review of human coronaviruses survival on environmental surfaces. Sci Total Environ. 2021;778:146191. https://doi.org/10.1016/j.scitotenv.2021.146191.

72. Paton S, Spencer A, Garratt I, Thompson K-A, Dinesh I, AranegaBou $\mathrm{P}$, et al. Persistence of severe acute respiratory syndrome coronavirus 2 (SARS-CoV-2) virus and viral RNA in relation to surface type and contamination concentration. Appl Environ Microbiol. 2021;87:e0052621. https://doi.org/10.1128/aem. 00526-21.

73. Biryukov J, Boydston JA, Dunning RA, Yeager JJ, Wood S, Reese $\mathrm{AL}$ et al. Increasing temperature and relative humidity accelerates inactivation of SARS-CoV-2 on surfaces. mSphere 2020; 5. https://doi.org/10.1128/mSphere.00441-20.

74. Bhardwaj R, Agrawal A. Likelihood of survival of coronavirus in a respiratory droplet deposited on a solid surface. Phys Fluids. 2020;32:061704. https://doi.org/10.1063/5.0012009.

75. Han W, Lin Z. Learning from "coffee rings": ordered structures enabled by controlled evaporative self-assembly. Angewandte Chemie-International Edition. 2012;51:1534-46. https://doi.org/ 10.1002/anie.201104454.

76. Bozic A, Kanduc M. Relative humidity in droplet and airborne transmission of disease. J Biol Phys. 2021;47:1-29. https://doi. org/10.1007/s10867-020-09562-5.

77. Grinchuk PS, Fisenko KI, Fisenko SP, Danilova-Tretiak SM. Isothermal evaporation rate of deposited liquid aerosols and the SARS-CoV-2 coronavirus survival. Aerosol Air Qual Res. 2021;21:200428. https://doi.org/10.4209/aaqr.2020.07.0428.

Publisher's note Springer Nature remains neutral with regard to jurisdictional claims in published maps and institutional affiliations. 